\title{
Increasing participation in incentive programs for biodiversity conservation
}

\author{
Michael G. Sorice, ${ }^{1,8}$ Chi-Ok Oh, ${ }^{2}$ Todd Gartner, ${ }^{3}$ Mary Snieckus, ${ }^{4}$ Rhett Johnson, ${ }^{5}$ and C. Josh Donlan ${ }^{6,7}$ \\ ${ }^{1}$ Department of Forest Resources and Environmental Conservation, Virginia Tech, Blacksburg, Virginia 24060 USA \\ ${ }^{2}$ Department of Community, Agriculture, Recreation and Resource Studies, Michigan State University, \\ East Lansing, Michigan 48824 USA \\ ${ }^{3}$ World Resources Institute, Washington, D.C. 20002 USA \\ ${ }^{4}$ American Forest Foundation, Washington, D.C. 20002 USA \\ ${ }^{5}$ The Longleaf Alliance, Andalusia, Alabama 36420 USA \\ ${ }^{6}$ Advanced Conservation Strategies, Midway, Utah 84049 USA \\ ${ }^{7}$ Department of Ecology and Evolutionary Biology, Cornell University Ithaca, New York 14853 USA
}

\begin{abstract}
Engaging private landowners in conservation activities for imperiled species is critical to maintaining and enhancing biodiversity. Market-based approaches can incentivize conservation behaviors on private lands by shifting the benefit-cost ratio of engaging in activities that result in net conservation benefits for target species. In the United States and elsewhere, voluntary conservation agreements with financial incentives are becoming an increasingly common strategy. While the influence of program design and delivery of voluntary conservation programs is often overlooked, these aspects are critical to achieving the necessary participation to attain landscape-scale outcomes. Using a sample of familyforest landowners in the southeast United States, we show how preferences for participation in a conservation program to protect an at-risk species, the gopher tortoise (Gopherus polyphemus), are related to program structure, delivery, and perceived efficacy. Landowners were most sensitive to programs that are highly controlling, require permanent conservation easements, and put landowners at risk for future regulation. Programs designed with greater levels of compensation and that support landowners' autonomy to make land management decisions can increase participation and increase landowner acceptance of program components that are generally unfavorable, like long-term contracts and permanent easements. There is an inherent trade-off between maximizing participation and maximizing the conservation benefits when designing a conservation incentive program. For conservation programs targeting private lands to achieve landscape-level benefits, they must attract a critical level of participation that creates a connected mosaic of conservation benefits. Yet, programs with attributes that strive to maximize conservation benefits within a single agreement (and reduce risks of failure) are likely to have lower participation, and thus lower landscape benefits. Achieving levels of landowner participation in conservation agreement programs that deliver lasting, landscape-level benefits requires careful attention not only to how the program structure influences potential conservation benefits, but also how it influences landowners and their potential to participate.
\end{abstract}

Key words: at-risk species; candidate conservation species; gopher tortoises; incentives; payments; private lands; voluntary conservation agreements.

\section{INTRODUCTION}

Engaging private landowners is critical to enhancing and maintaining biodiversity. In the United States, for example, a large proportion of habitat for at-risk species is located on private lands (GAO 1995). However, the perceived legal threat of land prohibitions from environmental laws like the U.S. Endangered Species Act (ESA) can create a perverse incentive that may discourage landowners from cooperating to manage

Manuscript received 28 October 2012; accepted 18 December 2012; final version received 4 February 2013. Corresponding Editor: R. L. Knight.

${ }^{8}$ E-mail: msorice@vt.edu their land for the benefit of ESA-listed and other at-risk species (Bean 1998, Lueck and Michael 2003, Zhang 2004). Recognizing the importance of private, working landscapes in at-risk species recovery and management, incentive-based programs are emerging that attempt to shift species management from a perceived liability into an asset. For example, the U.S. Department of Agriculture recently announced a US\$33 million initiative to protect and restore habitat for seven at-risk species through programs that provide regulatory certainty to private landowners that engage in voluntary conservation agreements (USDA 2012). This shift from a command-and-control to an incentive-based approach demonstrates a further recognition that protected areas alone are insufficient for species recovery and manage- 
ment, and that the ESA has been relatively ineffective at incentivizing species protection and recovery on private lands (Scott et al. 2001, Norris 2004).

Conservation incentive agreements that include direct payments are becoming increasingly common due to a suite of potential advantages, including their voluntary nature and goal of efficiently compensating individuals for providing a public good (Kelsey et al. 2008, Milne and Niesten 2009). Voluntary agreements can incentivize conservation behaviors on private lands by shifting both the perceived and realized benefit-cost ratios of engaging in activities that result in net conservation benefits for at-risk species. Financial inducements, regulatory predictability, and technical assistance decrease the costs and increase the benefits to private landowners who engage in conservation measures.

Voluntary conservation agreements are a potentially important policy tool for forest management. In the United States, over half of forest lands (56\%) are privately owned and provide habitat for more than 4600 at-risk, threatened, and endangered species (Smith et al. 2009, Stein et al. 2010). The family forest owner makes up the vast majority $(92 \%)$ of the 11 million private forest landowners in the United States. This subgroup includes families, individuals, trusts, estates, family partnerships, and other unincorporated groups of individuals that own forestland (Butler 2008).

An often overlooked but key factor to the success of voluntary conservation agreements is the level of participation. A critical mass of participation is needed in order to produce the landscape-level benefits needed for the recovery of at-risk species. Given the voluntary nature of conservation agreements, landowners must actively opt in to a program. Few studies have empirically investigated how program structures influence participation. Although regulatory assurances, bureaucratic processes, and financial incentives are influential drivers of participation (Langpap 2006, Womack 2008, Sorice et al. 2011), landowners' perceptions and incentive structures are likely to differ across cultures and landscapes. Regulatory assurances or predictability may be critical for some landowners; while for others, it may be of less importance (Sorice et al. 2011). More indirect factors, such as perceived efficacy, trust in the administering institution, and control of land-use decisions, may also play an important role in opting in to a voluntary conservation agreement (Womack 2008).

We employed a landowner-centered approach to better understand how program design and delivery influences participation. The central tenet of this approach is empathy for the landowner wherein the needs, desires, constraints, and experiences of landowners are placed at the forefront (Brown 2009). Landowner needs do not supplant the needs of the target species; rather, potential solutions are sought that integrate the needs of both, together with the goal of identifying tradeoffs landowners are willing to make to accommodate the needs of the target species.

We surveyed family forest landowners in the southeast United States, to examine their preferences for voluntary agreements to participate in a program to protect the gopher tortoise (Gopherus polyphemus). The gopher tortoise is federally listed as threatened under the ESA in Mississippi, Louisiana, and the Alabama counties west of the Mobile and Tombigbee Rivers. In July 2011, the U.S. Fish and Wildlife Service designated the eastern population of the gopher tortoise as a candidate for possible future listing under the ESA (USFWS 2011). The eastern portion of the gopher tortoise's range includes Alabama (east of the Mobile and Tombigbee Rivers), Florida, Georgia, and southern South Carolina. Increased efforts to protect and restore longleaf pine forests will be needed to prevent the eastern population of the gopher tortoise from further decline and listing under the ESA.

Operating in areas where the gopher tortoise is a candidate species, our hypothetical program focused on incentivizing conservation action upstream of regulatory triggers of the ESA, currently referred to as pre-listing conservation (USFWS 2012). The program would pay private landowners to maintain and manage their property for gopher tortoise habitat (see Gartner and Donlan 2011). We first explored overall interest in conservation agreements from private forest landowners. Second, we used a stated-preference choice experiment to estimate marginal utilities and implicit prices to examine the effect of important program components on participation, including land encumbrance, financial gain and payment structure, program administration, obligation, and conservation effectiveness. Last, we used the marginal utilities from our stated-preference choice experiment to predict the overall relative support for different types of conservation agreements. We specifically examined how to generate greater participation in conservation agreements that contain land easements and/or long-term contracts, components often promoted by conservation practitioners.

\section{Methods}

\section{Interest in conservation agreement programs}

We focused on family forest landowners in Alabama, Georgia, and Florida, who respectively account for $65 \%$, $58 \%$, and $30 \%$ of the forestlands in the three states (Butler 2008). Our sample consisted of 1051 landowners owning more than 250 acres who resided in counties with known gopher tortoise populations. They were randomly selected from mailing lists from the American Tree Farm System and the Longleaf Alliance $(n=2560$ landowners). These lists likely do not constitute a completely random sample of all family forest landowners. Members of both mailing lists are likely comprised of woodland owners who are knowledgeable about and actively engaged in managing their land. Tree farm landowners have considerable timber harvest and 
income generation motivations. Although Longleaf Alliance members engage in timber harvesting as well, their choice to cultivate longleaf pine indicates that there are drivers other than timber income that may be as equally important. Overall, the attitudes towards at-risk species and gopher tortoises in particular are likely quite diverse (M. Sneickus and R. Johnson, personal communication).

We mailed landowners a self-administered questionnaire using a multiple wave approach that included preliminary letter followed by the initial questionnaire mailing, a reminder letter with a replacement questionnaire, and a final postcard reminder (Dillman et al. 2009). Each landowner was given a brief description of the gopher tortoise and the proposed program that included a voluntary conservation agreement. A participating landowner would be paid for the number of conservation credits created and maintained on their property. Credits were defined as "a unit of gopher tortoise habitat that is determined by a science-based forest survey. For example, 300 acres $(\sim 121$ ha) of highquality gopher tortoise habitat would be worth 300 credits, while 300 acres of low-quality gopher tortoise habitat would be worth only 150 credits." In exchange for payments, a landowner would agree to conduct management activities that improve gopher tortoise habitat (i.e., prescribed burning every 2-4 years and control of invasive weeds); the program would pay for those activities. We first asked landowners to indicate their level of interest in the program on a scale from "not interested at all" (1) to "very interested" (4).

\section{Preferences for program components}

We then asked the landowners to respond to a series of six scenarios in which they would "maintain/restore gopher tortoise habitat and sell the 'credits' generated on your land." To examine preferences for individual components of a conservation agreement, we constructed hypothetical scenarios in which landowners compared programs that randomly varied in the level of individual components (Table 1). We used the literature and expert opinion to develop program components and their associated levels, and then revised them based on feedback from an in-person focus group of stakeholders comprised of conservation practitioners and landowners. For each scenario landowners had the option to choose between two alternative programs, or opt out and choose neither program. The opt-out option was included because it reflects the voluntary nature of conservation agreements.

Conservation easements are a common tool used by practitioners in the United States and elsewhere, but also can represent a land-use decision with high opportunity costs for landowners (Rissman et al. 2007). We included three options with respect to the conservation easement component: no easement, permanent donated easement, and permanent purchased easement. The easement types were distinguished by whether or not the easement is considered a charitable donation (i.e., donated) or income (i.e., sold). Research shows that program contract length is important to landowners (e.g., Sorice et al. 2011). With input from the focus group, we used four different levels of contract length, ranging from 10 to 100 years (Table 1). We used five different levels for profit margin, which represented the amount of profit a landowner receives from selling credits as a result from management activities that improve gopher tortoise habitat (Table 1). Payment structure reflected how the profit payments would be disbursed to the landowner (Table 1). Because landowners often highly value the ability to make their own land-use decisions (Peterson and Horton 1995, Bergmann and Bliss 2004, Knobloch and Cawley 2005), our survey included a program administration component that varied the level of control landowners would have over the management and land practices required by the program (Table 1). We structured the obligation component as the burden the landowner would have toward maintaining tortoise habitat after the contract ends and if the species were to become listed under the ESA at some future date. No obligation meant the landowner would not be responsible for maintaining any habitat. Baseline obligation meant the landowner would be required to maintain only the habitat that exists on the land prior to participating in the program. Full obligation meant that the landowner could be required to maintain all habitat, regardless of when it was created. We also included an expected conservation effectiveness component in the survey (Table 1). The expected range of increase in the number of gopher tortoises in the county as a result of improving habitat was included to assess how landowner expectations for outcomes (i.e., efficacy) influence their willingness to participate. It was based on expert opinion; conservation effectiveness ranged from no increase to a high level of increase (i.e., about $15 \%$, Table 1).

Stated-preference choice experiments assume that when landowners are faced with a choice between programs with multiple components they will make choices that maximize their personal satisfaction or utility. Although landowners consider all personally relevant factors that influence their decisions, one cannot account for all of them. Consequently, we used a probabilistic model to decompose the utility of participating $\left(U_{j}\right)$ into what is observable $\left(V_{j}\right)$ for a set of program components $(A)$ and into unobserved factors $\left(\varepsilon_{j}\right)$. This random utility model is represented as

$$
U_{j}=V_{j}(A)+\varepsilon_{j}
$$

We employed a main effects experimental design that required 48 scenarios. To reduce the burden on each respondent, we blocked these into eight survey versions and each landowner only responded to six scenarios (Louviere et al. 2000).

We used a random parameters logit (RPL with alternative-specific constant intercept) model to account 
TABLE 1. Program components and attributes used in constructing scenarios for hypothetical conservation agreements with private landowners focused on incentivizing improved management of gopher tortoise habitat.

\begin{tabular}{|c|c|}
\hline Program component and description & Levels \\
\hline \multicolumn{2}{|l|}{ Conservation easement } \\
\hline $\begin{array}{l}\text { A legally enforceable agreement between a landowner and a qualified land } \\
\text { protection organization for the purposes of permanently restricting real estate } \\
\text { development uses on a property. Landowner individually negotiates the terms } \\
\text { with the organization. The land remains as private property. }\end{array}$ & $\begin{array}{l}\text { 1) No easement } \\
\text { 2) Permanent donated easement } \\
\text { 3) Permanent sold easement }\end{array}$ \\
\hline \multicolumn{2}{|l|}{ Contract length } \\
\hline $\begin{array}{l}\text { The number of years landowners agree to perform the necessary land } \\
\text { management practices to restore, maintain, and/or improve gopher tortoise } \\
\text { habitat. }\end{array}$ & $\begin{array}{l}\text { 1) } 10 \text { years } \\
\text { 2) } 40 \text { years } \\
\text { 3) } 70 \text { years } \\
\text { 4) } 100 \text { years }\end{array}$ \\
\hline \multicolumn{2}{|l|}{ Profit margin } \\
\hline $\begin{array}{l}\text { Amount of profit landowners receive when a credit is sold. This amount is in } \\
\text { addition to the costs of management activities, which are covered by the } \\
\text { program. }\end{array}$ & $\begin{array}{l}\text { 1) } \$ 100 \text { per credit } \\
\text { 2) } \$ 200 \text { per credit } \\
\text { 3) } \$ 400 \text { per credit } \\
\text { 4) } \$ 800 \text { per credit } \\
\text { 5) } \$ 1600 \text { per credit }\end{array}$ \\
\hline \multicolumn{2}{|l|}{ Payment structure } \\
\hline The way landowners would receive profit payments from the sale of the credits. & $\begin{array}{l}\text { 1) } 25 \% \text { Year } 1,75 \% \text { Year } 5 \\
\text { 2) } 50 \% \text { Year } 1,50 \% \text { Year } 5 \\
\text { 3) } 75 \% \text { Year } 1,25 \% \text { Year } 5 \\
\text { 4) } 100 \% \text { Year } 1\end{array}$ \\
\hline \multicolumn{2}{|l|}{ Administration structure } \\
\hline $\begin{array}{l}\text { Level of control the program administrators have over creation of the land } \\
\text { management plan required in the conservation agreements, and } \\
\text { implementation of the practices outlined in the management plan. }\end{array}$ & $\begin{array}{l}\text { 1) Program staff (not landowner) makes } \\
\text { almost all land management decisions } \\
\text { 2) Landowner shares land management } \\
\text { decision making with program staff } \\
\text { 3) Landowner has complete } \\
\text { responsibility for land management } \\
\text { decisions }\end{array}$ \\
\hline \multicolumn{2}{|l|}{ Obligation } \\
\hline $\begin{array}{l}\text { Burden the landowner has toward maintaining gopher tortoise habitat once the } \\
\text { conservation agreements ends and if it becomes listed as an endangered } \\
\text { species under the Endangered Species Act. }\end{array}$ & $\begin{array}{l}\text { 1) No obligation } \\
\text { 2) Baseline obligation } \\
\text { 3) Full obligation }\end{array}$ \\
\hline \multicolumn{2}{|l|}{ Conservation effectiveness } \\
\hline $\begin{array}{l}\text { The expected increase in the number gopher tortoises in the county as a result } \\
\text { of landowners opting in to the program and improving habitat on their land. }\end{array}$ & $\begin{array}{l}\text { 1) No increase }(0 \%) \\
\text { 2) Low increase }(5 \%) \\
\text { 3) Moderate increase }(10 \%) \\
\text { 4) High increase }(15 \%)\end{array}$ \\
\hline
\end{tabular}

for preference heterogeneity amongst landowners (Train 2003). The RPL model tests the underlying assumption that individuals each may hold different preferences for each program component. Based on the assumption that parameters are randomly distributed in the population, multiple estimates are drawn to obtain a mean and standard deviation of the random parameter distribution. If the standard deviation does not differ from zero, then landowners have identical preferences for the program component. Because this research was exploratory and our goal was to identify attributes for the design of future incentive programs, we used an $\alpha$ level of 0.10 . We used 500 Halton draws to obtain stable parameter estimates for the RPL model.

The parameter estimates from the RPL model were used to calculate the amount of satisfaction or marginal utility that can be ascribed to a specific program attribute. We then used implicit prices as a useful standardized index for gauging the direction and magnitude of landowner preferences for program attributes. Implicit prices are the minimum amount of money a landowner must be compensated to voluntarily forgo his/her preferred level of a program component. Rather than focusing on the absolute dollar amounts, we consider implicit prices to be a measure of preference strength (Ritov and Kahneman 1997). We calculated implicit prices following Breffle and Morey (2000).

\section{Predicting participation}

Last, we aggregated and transformed the RPL model marginal utilities for program components and attributes into predicted probabilities, which serve as measures of relative support for the different programs. We examined predicted probabilities of opting in to a program by varying the easement requirement, contract length, profit margin, and program administration. We 
TABle 2. Parameter estimates (mean and standard deviation) of the random parameter logit model (log likelihood $=$ -1374.252 ; McFadden's $\rho^{2}=0.1622$ ).

\begin{tabular}{lrrr}
\hline \hline \multicolumn{1}{c}{ Parameter } & Average $\beta$ & SD & $\begin{array}{c}\text { Implicit } \\
\text { prices (\$) }\end{array}$ \\
\hline Intercept, a & $-1.3952^{*}$ & & 1443 \\
Conservation easement, a & & & \\
$\quad$ None & $0.6149^{*}$ & & -636 \\
$\quad$ Donated & $-0.2747^{*}$ & $0.4104^{*}$ & 284 \\
$\quad$ Purchased & $-0.3402^{*}$ & $0.4117^{*}$ & 352 \\
Contract length, b & $-0.2107^{*}$ & $0.1606^{*}$ & 218 \\
Contract length (quadratic), c & $0.2013^{*}$ & $0.0077^{*}$ & -208 \\
Profit margin, b & $0.3867^{*}$ & & \\
Payment structure, b & $-0.0908^{*}$ & $0.1658^{*}$ & 94 \\
Administration structure, a & & & \\
None & $-0.9709^{*}$ & & 1004 \\
Shared & $0.1503 \dagger$ & $0.3706^{*}$ & -156 \\
Complete & $0.8206^{*}$ & $0.6641^{*}$ & -849 \\
Obligation, a & & & \\
$\quad$ None & $0.2104^{*}$ & & -217 \\
$\quad$ Baseline & $0.1479^{*}$ & 0.0789 & -153 \\
$\quad$ Full & $-0.3583^{*}$ & 0.1452 & 371 \\
Conservation effectiveness, b & -0.0180 & 0.0883 & 19 \\
\hline
\end{tabular}

Notes: The mean represents a measure of satisfaction (or marginal utility) that can be ascribed to a specific program attribute (the more positive, the more the program attribute is preferred). If the standard deviation does not differ from zero then landowners have identical preferences for the program component. Implicit prices are a standardized index for gauging the direction and magnitude of landowner preferences for program components. Positive values are the amount landowners are willing to accept to receive more of a particular attribute. Negative values are the minimum amount of money a landowner must be compensated to voluntarily forgo their preferred level of a program component. Empty cells occur where there is no value to report. Parameters were modeled as (a) categorical, (b) linear, or (c) quadratic variables.

$\dagger P<0.10 ; * P<0.05$

held the payment structure, obligation, and conservation effectiveness constant. We generated six different conservation agreements that spanned the spectrum from programs that are typically promoted by conservation practitioners (e.g., permanent easements and long contract length) to those that are typically preferred by landowners (e.g., short-term commitments and large profits; Table 3).

\section{Results}

\section{Interest in conservation agreement programs}

Of the 1051 mail surveys sent to our target population, 533 were returned. Of these, 44 surveys were incomplete, leaving 489 useable surveys (46\%). About one-third of respondents (35\%) answered the hypothetical program-comparison scenario section of the survey by replying "neither" in every scenario when asked which program they would choose. Another $16 \%$ of respondents answered the set of questions by responding with some combination of answering "neither" and skipping scenarios. Thus, 251 landowners ( $51 \%$ of those that responded) indicated some interest in opting in to a conservation agreement; those respondents were included in our analyses.

General interest in the conservation agreement program was relatively low (mean $=2.3, \mathrm{SD}=1.1$, median $=2$, "slightly interested"). Almost a quarter of respondents $(24 \%)$ indicated they were "moderately interested" (i.e., 3) and $17 \%$ were "very interested" (i.e., 4). To follow up on the anticipated behavior of landowners opting out of all the program scenarios, we asked them to list the primary reason they were not interested in any of the programs. The most frequent response was concern about the "potential for government involvement" (33\%), followed by the "other" category (22\%; the vast majority of this category contained respondents who marked more than one reason) and landowners who were "generally not interested" (17\%). Only 3\% of respondents indicated noninterest due to the inadequacy of the incentives.

\section{Preferences for program components}

The results of the stated-preference choice experiment indicated that all of the program components, with the exception of conservation effectiveness, played an important role in landowner decision making. Conservation effectiveness was less important to landowners, indicated by its lack of statistical significance in our model (Table 2). With the exception of obligation, there was heterogeneity among landowners for the attributes of program components (Table 2). Overall, landowners were more likely to opt out and not choose a conservation agreement contract (Fig. 1a). Landowners preferred programs that did not require a permanent easement compared to a donated or purchased easement (Fig. 1b). Landowners preferred shorter contract lengths to longer ones; however, the significant quadratic effect for contract length suggests that the rate at which utility decreased was not constant (Fig. 1c). Landowners preferred greater profit (Fig. 1d), and indicated a preference for a payment structure that rewards the landowner later in the program (Fig. 1e). Landowners indicated a preference for having control over land management decisions within the administrative structure of the program (Fig. 1f). Landowners had a preference for no further obligation and did not prefer full obligation; however, they also indicated some preference for a baseline obligation (Fig. 1g).

Overall, landowners did not show a strong preference for opting in to conservation agreements; landowners would have to be compensated at least $\$ 1443$ to participate in a program (Table 2; all monetary amounts are reported in U.S. dollars). Negative implicit prices indicate a component attribute preference: it is the maximum a landowner is willing to pay to avoid lesspreferred levels of each program component. The program administration structure was the most influential of the program components, with the largest implicit prices. Landowners had a strong preference for assuming complete decision-making responsibility (-\$849) and 

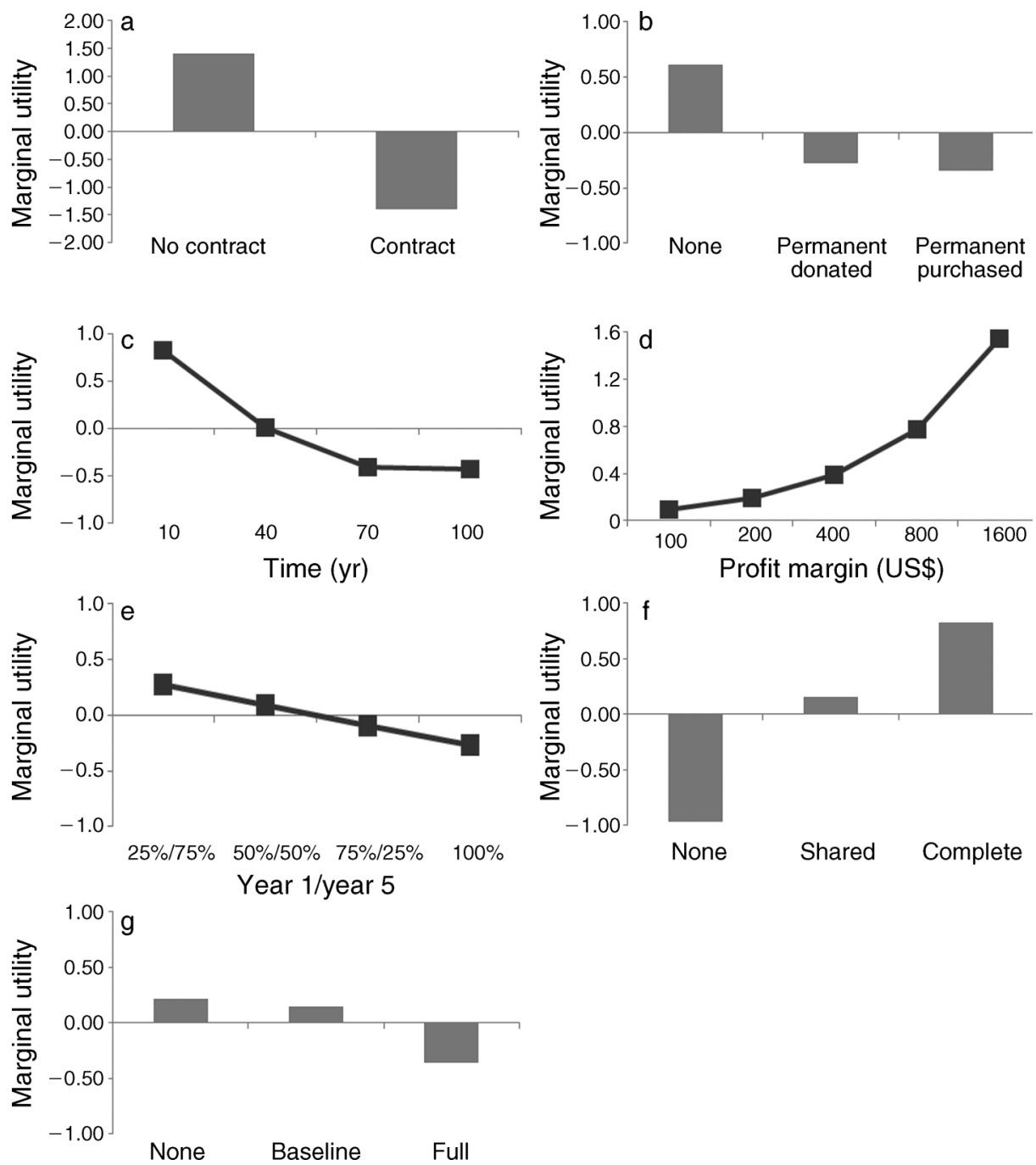

FIG. 1. Relative preferences (marginal utilities) of landowners for specific program attributes of a conservation agreement. Positive values indicate landowner preference, while negative values indicate a dislike for the attribute. (a) General preference for opting in or opting out, (b) requirement of a conservation easement, (c) length of contract, (d) profit margin, (e) payment structure, (f) administration structure, and (g) obligation. See Table 1 for definitions of program components and attributes.

a strong distaste for having no decision-making authority in land management decisions under the agreement (\$1004). Overall, landowners would need to be compensated about an additional $\$ 1853$ in order to accept a program that does not share decision-making power with landowners. Conservation easements had the second strongest influence on landowners' preferences (Table 2). Donated permanent easements and purchased permanent easements respectively required about $\$ 920$ (i.e., $|-\$ 636|+\$ 284$ ) and $\$ 988$ (i.e., $|-\$ 636|+\$ 352$ ) for landowners to accept them as program components. Finally, obligation influenced landowners' willingness to participate in programs with an estimated compensation of $\$ 588$ (i.e., $\$ 371+|-\$ 217|$ ) needed to get landowners to accept full obligation.

\section{Predicting participation}

Program 1, representing a more typical agreement proposed by conservation practitioners, had a predicted $34 \%$ opt-in rate (Table 3). This agreement consisted of a permanent donated easement, a 100-year contract, moderate profitability, assurances against future regulation, and some level of conservation effectiveness. If the profitability for the landowner is maximized, while all other components are held constant, the predicted opt-in rate increases to $59 \%$ (Table 3). Increasing the profitability for the landowner generated an expected increase in participation by a factor of 1.7. By changing the administration structure from no to shared decisionmaking authority increased predicted participation to 81\% (Program 3, Table 3). Changing it to complete 
TABLE 3. Landowner support for six conservation agreement programs that differ in conservation easement requirements, contract length, profitability, and administration structure.

\begin{tabular}{clcccc}
\hline \hline Program & \multicolumn{1}{c}{ Easement } & $\begin{array}{c}\text { Contract } \\
\text { length }(\mathrm{yr})\end{array}$ & $\begin{array}{c}\text { Profit margin } \\
\text { per credit }(\$)\end{array}$ & $\begin{array}{c}\text { Administration } \\
\text { structure }\end{array}$ & $\begin{array}{c}\text { Predicted } \\
\text { participation }(\%)\end{array}$ \\
\hline 1 & permanent donated & 100 & 400 & none & 34 \\
2 & permanent donated & 100 & $\mathbf{1 6 0 0}$ & none & 59 \\
3 & permanent donated & 100 & 1600 & shared & 81 \\
4 & permanent donated & 100 & 1600 & complete & 88 \\
5 & none & 100 & 1600 & complete & 94 \\
6 & none & $\mathbf{1 0}$ & 1600 & complete & 98
\end{tabular}

Notes: All other program components were held constant at the following attributes: baseline obligation, low conservation effectiveness, and split payment structure (Year 1, 25\%; Year 5, 75\%; see Table 1). Attributes in boldface type indicate stepwise changes made to the program. The scenarios serve to illustrate predicted landowner opt-in rates for programs ranging from those that are typically advocated by conservation practitioners to those that are highly preferred by landowners.

decision-making authority increased it further to $89 \%$ (Program 4, Table 3). Removing the easement requirement and allowing for shorter contracts further increased the predicted opt-in rate (Programs 5 and 6, Table 3).

\section{DisCUSSION}

Agency theory is the dominant theory supporting the use of incentives whereby a principal (e.g., society, as represented by government) aligns the goals of an agent (e.g., an individual landowner) with its own goals (Joireman et al. 2001). From this perspective, obtaining a desired behavioral change is largely a matter of applying the correct incentive; after which, one must merely determine an efficient pricing scheme. This payfor-change approach, however, does not recognize that the act of opting into a program is itself an interaction with its own inherent set of incentives. Landowners perceive benefits and infer potential costs of participating based on how a program is structured and administered. Our results suggest that these perceptions play a critical role in potential participation in conservation incentive agreements and programs.

Our landowner-centered approach emphasizes landowner preferences rather than top-down program structures based on the a priori preferences of a conservation organization. It allowed us to evaluate the likelihood of private landowners opting in to a conservation agreement based on specific aspects of the program. Despite the possibility of profiting from land managed to benefit an at-risk species, we found that landowners were generally disinterested in the proposed program. Approximately half of the respondents showed little or no interest in even providing preferences for the conservation agreement scenarios, citing multiple concerns including issues regarding government involvement. However, only $3 \%$ indicated that the financial incentives were not adequate. Thus, similar to previous research on incentive programs and at-risk species (Womack 2008, Sorice and Conner 2010, Sorice et al. 2011) opting out of conservation agreements may occur more for social reasons, such as distrust, as opposed to a lack of financial incentives. With a high percentage of forest landowners opting out of the hypothetical programs, the levels of predicted participation were likely somewhat inflated and interpretation of these results may be limited to landowners who are interested in the program. It is, however, a reasonable goal for conservation programs to work toward landscape-level outcomes by focusing on maximizing the potential participation of forest landowners who are at least somewhat interested but otherwise not participating, rather than on those that show no interest. Participation would be expected to increase as the market becomes more established and participating landowners spread word of their positive experiences through their social networks.

Of the forest landowners that showed some preference for opting in to a conservation agreement, there was significant heterogeneity in landowner preferences across all program attributes with the exception of conservation effectiveness. This observed heterogeneity fits with the view that landowners are highly independent, each having different views on private property rights, trust in government, and endangered species conservation (Peterson and Horton 1995, Raymond and Olive 2008). Our model provides estimates that account for individual heterogeneity, but does not identify the cause of differing preferences. A possible explanation for the heterogeneity is a shift in land use from a focus on production (i.e., forestry) to recreation (e.g., vacation home) or shifts in local culture (Gosnell and Abrams 2009). The observed heterogeneity also provides insight into the process of designing conservation agreements. A landowner-centered design approach recognizes the suite of motivations landowners possess for managing their land and attempts to incorporate them into the design process. This custom, bottom-up approach recognizes local culture, preferences, and attitudes. A landowner-centered design approach may result in novel collaborative solutions as opposed to improving existing programs (Brown 2009).

Despite the observed heterogeneity, there were some clear preferences and distastes for some program attributes among landowners. Landowners consistently did not show a preference for a program with high 
conservation effectiveness. Our results suggest that landowner knowledge of how their participation would affect gopher tortoises was not actively incorporated into their decision-making process. One interpretation may be that landowners care little about conservation outcomes for the gopher tortoise; however, their low preference for conservation effectiveness may be reflected relative to other priorities within the suite of incentives. The lack of statistical significance may not necessarily indicate that efficacy is unimportant to landowners; rather, it may be less important than ensuring that the landowners' self-interested motivations related to enhancing income, minimizing risk, and retaining autonomy are adequately addressed.

Not surprisingly, landowners were generally adverse to permanent conservation easements. Permanent or perpetual easements may act as a disincentive to opt in to a conservation agreement. Land easements can reduce a landowner's ability to adapt to changing conditions and land-use objectives, potentially reduce future income, and generate intergenerational inequity or conflict (Mahoney 2002, Kabii and Horwitz 2006). The differences in the implicit prices between the most preferred attribute of no easement and the least preferred attribute of purchased easement (\$988) suggest that landowners have strong preferences when it comes conservation easements.

Consistent with previous research, landowners preferred shorter-term contracts (Olenick et al. 2005, Womack 2008, Sorice et al. 2011, Rodriguez et al. 2012). Landowners showed a decreasing preference for longer-term contracts, but were generally indifferent between 70- and 100-year contracts. This indifference may be related to intergenerational issues or future discounting. Although landowners preferred 10-year contracts, their relative preference for 40 -year contracts was neutral. An optimal contract length may exist that balances incentivizing maximum landowner participation with the biodiversity value of longer contract lengths.

Landowners generally believe that they should be compensated for protecting at-risk or endangered species (Brook et al. 2003, Kreuter et al. 2006, Raymond and Olive 2008). Landowners showed a strong preference for increasing their profit. Although financial incentives are necessary, payments alone are likely to be insufficient to incentivize high levels of participation in conservation agreement programs. Financial incentives allay concerns related to potential income loss, but they may do little to treat concerns regarding intergenerational equity and the loss of autonomy. Allowing the landowner at least some autonomy in making land management decisions likely leads to increased participation over and above what payments can achieve. Landowners also showed a preference for spreading profit payments over time. The most-preferred attribute was splitting a profit payment between year $1(25 \%)$ and year 5 (75\%). Landowners actually disliked a conserva- tion agreement where the entire profit payment was delivered in year 1. This effect may be due to perceived tax benefits of amortizing profit payments. Regardless of the mechanism, a landowner preference for staged payments is advantage for practitioners that are designing conservation agreements that attempt to be more outcome based (Kapos et al. 2008).

Similar to other studies, the landowners we surveyed expressed concern about the regulatory risks associated with protecting at-risk species (Langpap 2006, Sorice et al. 2011). They were unwilling to assume a complete obligation to continue to maintain gopher tortoise habitat, should the species become ESA listed. Landowners were, however, willing to assume some risk: they indicated a willingness to abide by a baseline (i.e., nonet-loss) standard, in which they would be required to maintain any gopher tortoise habitat that existed prior to participating in the program. This standard is analogous to Safe Harbor Agreements for species that are listed under the ESA (Bean et al. 2001). There are multiple possible reasons for the positive preference for a baseline obligation. Our study focused on an ESA candidate species, which is not listed as threatened or endangered. Landowners may perceive a lower level of risk that the species may become listed in the future. Alternatively, landowners with strong concerns about government involvement, which is related to obligation, may have self-selected out of our sample by not responding to the program scenarios. Research focused on the effect of future regulation on landowner decisionmaking has produced mixed results. In some cases, regulatory concerns have not been found to drive landowner decisions, while in other cases it appears to be a dominant influencing factor with respect to opting in to conservation agreements (e.g., Langpap 2004, Sorice 2012). Regardless of the reason, our results demonstrate that providing some level of assurances against future obligation is likely to increase landowner participation in voluntary conservation agreements.

Autonomy is a fundamental value of landowners that influences their willingness to engage in conservation agreements or programs (Peterson and Horton 1995, Bergmann and Bliss 2004, Knobloch and Cawley 2005). Programs that are implemented with an autocratic administration structure inhibit landowners' ability to make self-directed choices and are likely to be perceived as controlling; these factors are likely to lower participation (DeCaro and Stokes 2008). We found that allowing the landowner to share in the decision-making processes within the administration structure of a conservation program led to increased participation. Although we included complete autonomy in our survey to explore the effect of shifting the decision-making power from the program administrators to the landowner, offering participating landowners complete responsibility over land management decisions under a conservation agreement is likely unrealistic and undesirable. Nonetheless, how decision-making authority is 
shared within the program was the single most important factor with respect to landowner preferences. If conservation practitioners can engage in co-management with participating landowners, they may be more likely to engage with landowners in programs with attributes that may less desirable to landowners, but highly desirable by the counterparty (e.g., long-term contracts and permanent easements). Supporting autonomy may also lead to increased conservation outcomes by participating landowners, since autonomy can lead to integration of conservation behaviors into a landowner's sense of self and stewardship ethics, driving future behavior (Frey 1997, Deci et al. 1999).

Conservation incentive agreements can be potent biodiversity conservation tools on private lands because they attempt to harness market principles to turn a conservation target (e.g., at-risk species) into an asset (Ferraro and Kiss 2002). However, conservation outcomes associated with conservation agreements, which are usually voluntary, are a direct function of participation. Thus, there is an inherent trade-off between maximizing participation and maximizing the conservation benefits of a single agreement when designing a conservation incentive program. To achieve landscapelevel benefits, conservation programs targeting private lands must attract a critical level of participation that leads to a desired mosaic of conservation benefits (e.g., improved habitat on private lands that complement public land management). Programs with attributes that strive to maximize conservation benefits within a single agreement (and reduce risks of failure) are likely to have low participation, and thus low landscape benefits. For example, the use of Conservation Candidate Agreements with Assurances in the United States has been limited: a total of 25 have been finalized since 1999 (Donlan et al., in press). Conversely, programs with attributes that are highly preferred by private landowners may enjoy widespread participation, but also will have higher risks of failing to produce long-term net conservation benefits. Our landowner-centered approach provides a quantitative and cost-effective exploratory tool to assess those inherent trade-offs by predicting participation rates of programs that differ in certain attributes. This approach should prove valuable across different socioeconomic and ecological settings in designing conservation incentive programs that recognize landowner needs. Achieving levels of landowner participation in conservation agreement programs that deliver lasting, landscape-level benefits requires careful attention not only to how the program structure influences potential conservation benefits, but also how it influences landowners and their potential to participate.

\section{ACKNOWLEDGMENTS}

We thank our colleagues for input and discussion: $\mathrm{T}$. Cutsinger, M. Elmore, S. Ginger, and W. Harrison. This work was supported by Wildlife Conservation Society through the Wildlife Action Opportunities Fund (established by support from the Doris Duke Charitable Foundation), American Forest Foundation, Longleaf Alliance, and Cornell University.

\section{Literature Cited}

Bean, M. J. 1998. The Endangered Species Act and private land: four lessons learned from the past quarter century. Environmental Law Reporter 28:10701-10710.

Bean, M. J., J. P. Jenny, and B. van Eerderi. 2001. Safe harbor agreements carving out a new role for NGOs. Conservation in Practice 2:8-15.

Bergmann, S. A., and J. C. Bliss. 2004. Foundations of crossboundary cooperation: resource management at the publicprivate interface. Society and Natural Resources 17:377-393.

Breffle, W. S., and E. R. Morey. 2000. Investigating preference heterogeneity in a repeated discrete-choice recreation demand model of Atlantic salmon fishing. Marine Resource Economics 15:1-20.

Brook, A., M. Zint, and R. De Young. 2003. Landowners' responses to an Endangered Species Act listing and implications for encouraging conservation. Conservation Biology 17:1638-1649.

Brown, T. 2009. Change by design. HarperCollins, New York, New York, USA.

Butler, B. J. 2008. Family forest owners of the United States, 2006. General Technical Report NRS-27. U.S. Department of Agriculture, Forest Service, Northern Research Station, Newtown Square, Pennsylvania, USA.

DeCaro, D., and M. Stokes. 2008. Social-psychological principles of community-based conservation and conservancy motivation: attaining goals within an autonomy-supportive environment. Conservation Biology 22:1443-1451.

Deci, E. L., R. Koestner, and R. M. Ryan. 1999. A metaanalytic review of experiments examining the effects of extrinsic rewards on intrinsic motivation. Psychological Bulletin 125:627-668.

Dillman, D. A., J. D. Smyth, and L. M. Christian. 2009. Internet, mail, and mixed-mode surveys. Third edition. John Wiley, Hoboken, New Jersey, USA.

Donlan, C. J., T. Gartner, T. Male, and Y. Li. In press. Incentivizing species conservation upstream of regulation. Environmental Policy and Law.

Ferraro, P. J., and A. Kiss. 2002. Direct payments to conserve biodiversity. Science 298:1718-1719.

Frey, B. S. 1997. Not just for the money: an economic theory of personal motivation. Edward Elgar, Northampton, Massachusetts, USA.

GAO. 1995. Endangered Species Act: information on species protection on nonfederal lands. Report GAO/RCED-95-16. United States General Accounting Office, Washington, D.C., USA.

Gartner, T., and C. J. Donlan. 2011. Insights from the field: forests for biodiversity. World Resources Institute, Washington, D.C., USA.

Gosnell, H., and J. Abrams. 2009. Amenity migration: diverse conceptualizations of drivers, socioeconomic dimensions, and emerging challenges. GeoJournal 76:303-322.

Joireman, J. A., P. A. M. Lange, M. Vugt, A. Wood, T. V. Leest, and C. Lambert. 2001. Structural solutions to social dilemmas: a field study on commuters' willingness to fund improvements in public transit. Journal of Applied Social Psychology 31:504-526.

Kabii, T., and P. Horwitz. 2006. A review of landholder motivations and determinants for participation in conservation covenanting programmes. Environmental Conservation 33:11-20.

Kapos, V., et al. 2008. Calibrating conservation: new tools for measuring success. Conservation Letters 1:155-164.

Kelsey, J., C. B. Kousky, and K. E. Sims. 2008. Designing payments for ecosystem services: lessons from previous experience with incentive-based mechanisms. Proceedings of the National Academy of Sciences USA 105:9465-9470. 
Knobloch, F., and R. M. Cawley. 2005. Endangered species protection and ways of life: beyond economy and ecology. Pages 131-146 in J. F. Shogren, editor. Species at risk: using economic incentives to shelter endangered species on private lands. University of Texas Press, Austin, Texas, USA.

Kreuter, U., M. Nair, and D. Jackson-Smith. 2006. Property rights orientations and rangeland management practices: Texas, Utah and Colorado. Rangeland Ecology and Management 59:632-639.

Langpap, C. 2004. Conservation incentives programs for endangered species: an analysis of landowner participation. Land Economics 80:375-388.

Langpap, C. 2006. Conservation of endangered species: Can incentives work for private landowners? Ecological Economics 57:558-572.

Louviere, J. J., D. Hensher, and J. Swait. 2000. Stated choice methods: analysis and application. Cambridge University Press, Cambridge, UK.

Lueck, D., and J. A. Michael. 2003. Preemptive habitat destruction under the endangered species act. Journal of Law and Economics 46:27-60.

Mahoney, J. D. 2002. Perpetual restrictions on land and the problem of the future. Virginia Law Review 88:739-787.

Milne, S., and E. Niesten. 2009. Direct payments for biodiversity conservation in developing countries: practical insights for design and implementation. Oryx 43:530.

Norris, S. 2004. Only 30: a portrait of the Endangered Species Act as a young law. BioScience 54:288-294.

Olenick, K. L., U. P. Kreuter, and J. R. Conner. 2005. Texas landowner perceptions regarding ecosystem services and cost-share land management programs. Ecological Economics 53:247-260.

Peterson, T. R., and C. C. Horton. 1995. Rooted in the soil: how understanding the perspectives of landowners can enhance the management of environmental disputes. Quarterly Journal of Speech 81:139-166.

Raymond, L., and A. Olive. 2008. Landowner beliefs regarding biodiversity protection on private property: an Indiana case study. Society and Natural Resources 21:483-497.

Rissman, A. R., L. Lozier, T. Comendant, P. Kareiva, J. M. Kiesecker, M. R. Shaw, and A. M. Merenlender. 2007. Conservation easements: biodiversity protection and private use. Conservation Biology 21:709-718.

Ritov, I., and D. Kahneman. 1997. How people value the environment: Attitudes versus economic values. Pages 33-51 in M. H. Bazerman, D. M. Messick, A. E. Tenbrunsel, and K. A. Wade-Benzoni, editors. Environment, ethics, and behavior. New Lexington Press, San Francisco, California, USA.

Rodriguez, S. L., M. N. Peterson, F. W. Cubbage, E. O. Sills, and H. D. Bondell. 2012. Private landowner interest in market-based incentive programs for endangered species habitat conservation. Wildlife Society Bulletin 36:469-476.

Scott, J. M., F. W. Davis, R. G. McGhie, R. G. Wright, C. Groves, and J. Estes. 2001. Nature reserves: Do they capture the full range of America's biological diversity? Ecological Applications 11:999-1007.

Smith, W. B., P. D. Miles, C. H. Perry, and S. A. Pugh. 2009. Forest resources of the United States, 2007. General Technical Report WO-78. U.S. Department of Agriculture, Forest Service, Washington Office, Washington, D.C., USA.

Sorice, M. G. 2012. Retooling the traditional approach to studying the belief-attitude relationship: explaining landowner buy-in to incentive programs. Society and Natural Resources 25:499-512.

Sorice, M. G., and J. R. Conner. 2010. Predicting private landowner intentions to enroll in an incentive program to protect endangered species. Human Dimensions of Wildlife 15:77-89.

Sorice, M. G., W. Haider, J. R. Conner, and R. B. Ditton. 2011. Incentive structure of and private landowner participation in an endangered species conservation program. Conservation Biology 25:587-596.

Stein, S. M., M. A. Carr, R. E. McRoberts, L. G. Mahal, and S. J. Comas. 2010. Threats to at-risk species in America's private forests. General Technical Report NRS-73. U.S. Department of Agriculture, Forest Service, Northern Research Station, Newtown Square, Pennsylvania, USA.

Train, K. E. 2003. Discrete choice methods with simulation. Cambridge University Press, Cambridge, UK.

USDA. 2012. USDA and Interior announce wildlife conservation efforts to support local economies and preserve farm and ranch traditions. USDA press release, March 8, 2012. U. S. Department of Agriculture, Washington, D.C., USA. http:// www.usda.gov/wps/portal/usda/usdahome?contentid=2012/ 03/0088.xml\&contentidonly=true

USFWS (U.S. Fish and Wildlife Service). 2011. Twelve-month finding on a petition to list the gopher tortoise as threatened in the eastern portion of its range. Federal Register 76:45130-45162.

USFWS (U.S. Fish and Wildlife Service). 2012. Endangered and threatened wildlife and plants; expanding incentives for voluntary conservation actions under the Endangered Species Act. Federal Register 77:15352-15354.

Womack, K. 2008. Factors affecting landowner participation in the candidate conservation agreements with assurances program. Thesis. Utah State University, Logan, Utah, USA.

Zhang, D. 2004. Endangered species and timber harvesting: the case of red-cockaded woodpeckers. Economic Inquiry 42:150-165. 